\title{
ARE POLISH PRIMARY CARE PRACTITIONERS SOCIAL ENTREPRENEURS?
}

\author{
HUBERT WIERCIŃSKI \\ INSTITUTE OF ETHNOLOGY AND CULTURAL ANTHROPOLOGY \\ THE UNIVERSITY OF WARSAW
}

In this article I explore the range of entrepreneurial roles played by doctors working in Polish Primary Health Care [Podstawowa Opieka Zdrowotna - POZ]. I use the division into social and strictly business entrepreneurship - whose source comes from economic sciences - in order to examine what entrepreneurial values rural/small town doctors and their city colleagues recognise and use in their practices. POZ is mainly carried out in private clinics contracted by the National Health Fund [Narodowy Fundusz Zdrowia - NFZ], therefore I look at the values associated with entrepreneurship. I consider these values as visibly altering doctor-patient encounters, thus I analyse doctor's strategies for establishing his/ her formal and informal relations with patients. I focus my attention on the specific forms of experiencing time in primary care, namely short and long time structures, which I recognise as crucial for interactions between practitioners and their patients. Finally, I put forward the thesis that much of the interaction in POZ offices has the characteristics of symbolic exchange - the reciprocal forms of doctor-patient interactions transfer these encounters beyond purely medical interventions to spaces of mutual cooperation, attachment and trust.

W artykule analizuję spektrum ról odgrywanych przez lekarzy pracujących w polskiej Podstawowej Opiece Zdrowotnej (POZ). W tym celu posiłkuję się podziałem na przedsiębiorczość społeczną i stricte biznesową, którego źródło pochodzi z nauk ekonomicznych. Ponieważ POZ realizowana jest głównie w prywatnych przychodniach kontraktowanych przez Narodowy Fundusz Zdrowia, przyglądam się, jakie wartości związane z przedsiębiorczością przyświecają lekarzom pracującym na wsiach i małych miasteczkach oraz w dużych ośrodkach miejskich. Uważam, że te wartości kształtują relacje pomiędzy lekarzami a pacjentami. Analizuję więc strategie lekarzy, przy pomocy których tworzą oni oraz utrzymują formalne i nieformalne relacje z podopiecznymi. Przedstawiam tu dwie podstawowe struktury czasowe („długą” i „krótką”), pomocne lekarzom POZ w nawiązywaniu relacji w pacjentami. Wreszcie, stawiam tezę, iż znaczna część interakcji w gabinetach POZ ma cechy wymiany symbolicznej, która przenosi kontakty lekarzy z pacjentami ze zmedykalizowanej i sformalizowanej przestrzeni, do świata wartości takich, jak współpraca, przywiązanie i poczucie zaufania.

Ke yw o rds: Poland, primary care, social entrepreneurship, doctor-patient relations 
Researchers have proved that relations between patients and doctors visibly alter the quality of diagnosis and treatment (Piątkowski 20I5; Piątkowski and Nowakowska 20I2). Many conditions require not only equipment and doctors' skills, but also stimulating impulses that build a sense of trust and care between patients, on the one hand, and practitioners and the institutions they represent, on the other.

The considered relations and experiences are vulnerable to political and economic reconfigurations of late modernity, which doubtlessly shape doctor's values and roles (Rylko-Bauer and Farmer 2002; Mulligan 2015; Keshavjee 20I4; Piątkowski and Nowakowska 20I2). Thus, inspired by Lorna's Rhodes (1996) reflections on biomedical culture and Sławomir's Czachowski's (2002, 2005) studies on "family doctors", I aim to look at the roles played by practitioners in a medical sector distinctive to majority of contemporary healthcare systems - primary care. As the "Health for All" strategy announced in Alma Ata in 1978 and the WHO's "Ljubljana Charter" state (Cueto 2004; Janes et al. 2006), primary care is fundamental to contemporary global health. Extensive multidisciplinary research has revealed complex primary care tasks and contexts. As Cezary Włodarczyk demonstrated, it is more than just a form of medical practice more than anything, it is "a category of health policy" (Włodarczyk 2000, 213). Public health and social researchers recognize primary care practitioner's cooperation with state institutions and their engagement in providing social aid and prevention (Czachowski, 2002, 2005, Kowalska-Bobko 2017). However, the quantitative perspective employed by most of the above-mentioned academics, although informative, does not exhaust all primary care matters. Patient-doctors encounters have their unique cultural scenarios, gestures, and rhythms that frame the reciprocal process of diagnosis, treatment, and knowledge transfer. Together, these constitute an ethnographically thick ritual of care based on empathy and trust, whilst simultaneously introducing relations of power. Moreover, ethnographers like Jane Farmer and Sue Kilpatrick (2009), Sue Kilpatrick et al. (2009), and Lisa Iversen (2002) have demonstrated, that primary care practitioners are also rooted in local communities and possess a cultural capital, potentially turning them into socially engaged medical professionals - "social entrepreneurs" working for the community.

However, I am not entirely sold by these enthusiastic declarations. I see the latter research as inconclusive and, although conducted in various geographic and cultural settings, not covering all primary care economic and political contexts. To illustrate this, I focus my attention in this paper on Polish primary health care - the Podstawowa Opieka Zdrowotna (POZ) - which since 1997 has been decentralised and - to some extent - opened up to the market, turning many doctors into entrepreneurs, but presumably not "social". These doctors revealed a strong attachment to private property and business entrepreneurship. Only a portion of them perceived their roles closer to Farmer (2009), Kilpatrick, (2009) and Iversen's (2002) concepts of social entrepreneurship. 
I consider this state of affairs to have its roots in Poland's recent socio-political history. Since 1989 the country has been undergoing massive reconstructions - first the transition and later EU accession. These reconfigurations clearly altered the doctors' values, which were exposed to new economies and policies favouring entrepreneurship and independence from the state. Thus, I ask how and what entrepreneurial roles POZ doctors recognise in Polish post-transformation healthcare. I explore the socio-economic frameworks establishing doctors' duties and analyse the factors shaping their work views. Later, I seek strategies - revealed by rural/small town doctors and their city colleagues - of maintaining formal and informal relations with patients. Here I focus my attention on the specific forms of experiencing time in primary care, namely short and long time structures establishing frames for relations between doctors and patients. Finally, I investigate the observed reciprocal forms of doctor-patient interactions, which I consider as a sine qua non for doctors' social, although not fully entrepreneurial, engagement. I argue that the observed symbolic reciprocity transfers patient-doctor encounters beyond purely medical interventions, into spaces founded on cooperation, attachment, and mutual trust.

\section{THE METHODS, THE FIELD AND THE STUDY GROUP}

The ethnographic research with practitioners working in POZ clinics was conducted from 2014 to 20I8. The research encompassed POZ clinics in Podlasie and Mazowsze voivodeships. The majority of these clinics were run by two to four doctors, with the exception of one bigger in Warsaw and two in Białystok. The surgeries usually served a population of up to six thousand patients, with doctors sharing administrative duties. The larger clinics had their own supervisory board coordinated by the doctor-owners.

Forty five interviews were conducted in seventeen different clinics, three of them in Warsaw, one in a rural area nearby Warsaw, seven in Białystok, and six in a rural/ small town area of Podlasie. Due to legal restrictions and the owners' reluctance, the observations were limited to only two surgeries - one in Białystok and one in Warsaw. More fruitful observations resulted from participation in the surprisingly socially vibrant gatherings of the Porozumienie Zielonogórskie ("Zielona Góra Agreement"), an association of healthcare employers representing the collective interests of POZ doctors. There, I observed how doctors interacted, exchanged knowledge, and shared experiences related to their jobs, patients, and finally lives inseparably tied to their profession.

The clinics, despite being to some extent standardised thanks to rigid state contracts, are also diverse and dependant on regional demography, economic competitiveness, and human resources (Holecki et al. 2013). Warsaw is commonly highlighted by the medical community as a place with a weaker state role in providing care. The local healthcare system is augmented by the private sector based on voluntary insurance 
contributions and pay-per-visit appointments. In this area I observed a high turnover of patients and doctors sharing job duties between independent institutions and those offering state-refunded services. Consequently, the doctors rarely displayed an attachment to a particular clinic and its patients. Surprisingly, almost none of the Warsaw doctors had ever spoken about this uneasy fact for POZ practitioners. Moreover, in the investigated clinics - literally entrepreneurial medical companies - as well as primary care services, patients could attend pay-per-visit secondary care consultations and lifestyle consultations with cosmetologists, psychologists, and diet counsellors.

In Podlasie the state plays a much more dominant role in providing healthcare, although some minor independent clinics offer competitive services. In the investigated clinics the doctors' personal attachments were strong, with almost all my interlocutors occupying full-time positions in primary care. Consequently, the turnover of patients is notably lower than in Warsaw. Informants, especially those who worked in the rural/ small-town area, claimed that POZ clinics still play a distinguished role in the local communities, thereby evoking some references to Farmer's and Kilpatrick's (2009) findings. The similarities between their conclusions and the data under discussion here, are mostly visible in the long-lasting, deep-rooted doctor-patient relationships and practitioners paying more attention to patients' social and personal matters. Many doctors lived in the vicinity and shared neighbourhood relations with patients. In some cases, the doctors were attached to the land by property rights or affinity.

Before taking up positions in POZ, many informants had worked in hospitals. Some of them occupied consulting positions in pharmaceutical companies. In the I990s, these doctors were unable to find permanent positions in healthcare. Instead, they took advantage of a rapidly expanding pharmaceutical sector, where they were exposed to culture of capitalism.

Such diverse professional experience resulted in doctors occupying different economic positions. Most of the older practitioners were the owners of medical centres, holding economic capital. Consequently, a majority of the younger practitioners were salaried employees. Some of the respondents occupied the weakest position of "resident". This, however, did not prevent them from sharing similar economic values with their experienced colleagues, as well as perspectives on healthcare and relations with patients. They often spoke about the healthcare system as a healthcare market, rather than as an institution of social welfare.

\section{ENTREPRENEURSHIP(S) AND PRIMARY CARE}

Entrepreneurship is a term commonly used outside the field of anthropology predominately in economy and management studies. Nevertheless, it is a phenomenon universally present across the globe. Consequently, there are many culturally-grounded 
ideas for entrepreneurship reaching beyond narrowly understood business activity. Entrepreneurship inspires deeper human relations of trust and affinity. It serves as a modus operandi for ritualised behaviours, establishes hierarchies, and creates spaces for dynamic cultural activity. However, entrepreneurship, as non-anthropologists suggest, is an intentional act of identification, evaluation, and exploitation of opportunities for introducing new products or services in order to accumulate wealth (Certo and Miller 2008). Entrepreneurs consequently aim to sell their offer, and focus their actions on generating profit and building their status.

Hence, how should social entrepreneurship be defined? The theory of social entrepreneurship lacks the characteristic of accuracy that is found in the economy (Thompson 2002). The term is open to critical interpretation, however, two aspect are crucial, namely: references to business entrepreneurship and socially oriented approaches making social entrepreneurship a unique form of socially engaged activity. As Trevis Certo and Toyah Miller propose, it

"(...) involves the recognition, evaluation, and exploitation of opportunities that result in social value - the basic and long-lasting needs of society - as opposed to personal and shareholder wealth" (Certo and Miller 2008, 267).

John L. Thompson complements this definition:

"Many social entrepreneurs, then, are people with the qualities and behaviours we associate with the business entrepreneur but who operate in the community and are more concerned with caring and helping than with "making money". In many cases, they help change people's lives because they embrace important social causes" (Thompson 2002, 4I3).

In order to achieve social changes, social entrepreneurs play the roles of agents of innovation, adaptation, or knowledge distribution. As the latter one requires longlasting evaluation and careful observations, the measurements of socially-oriented performances differ from those of business activities, which prefer standardised and calculable methods (Austin et al. 2006).

How then, does the concept of social entrepreneurship work in the field of medical anthropology and primary care? The most informative seem to be ethnographically grounded reflections brought by Farmer and Kilpatrick (2009), Kilpatrick et al. (2009) and Iversen et al. (2002). Farmer and Kilpatrick state as follows:

A social entrepreneur is someone who formally and informally generates community associations and networking that produces social outcomes (Farmer and Kilpatrick 2009, I652).

Although concise, this definition is more flexible than previously quoted concepts, which see social entrepreneurship as a voluntary form of activity, although formalised and implemented by dedicated institutions. They miss the broad range of informal engaged actions, peoples' interactions, and intentions, all evidently matching the 
sense of pro-community commitment. What is not missed, but less exposed, is social entrepreneurs capabilities of generating associations where culturally-grounded actions and ideas emerge. These abilities, as Farmer and Kilpatrick (2009), Kilpatrick et al. (2009) and Iversen et al. (2002) suggest, result from socio-cultural and geographical contexts in which people with a certain capital (education, authority, trust) work. Rural primary care doctors seem to perfectly illustrate this thesis. They are supposed to be intensively devoted to their practice, as contrary to city doctors, they have intimate knowledge about people who are often not only their patients, but friends, neighbours, or relatives. As Kilpatrick et al. (2009) argue, they occupy a doubleposition: professional-external to the community, and native-internal, allowing them to comprehend community matters. They are able to diffuse and navigate through two separate social dimensions, mixing strong personal relationships and weaker ties with more distant people and their needs.

As WHO states, primary care is the set of procedures which aim to cover people's common health-related needs to keep them healthy and happy in their communities. This is especially visible in smaller communities, where doctors must be fluent in elements of secondary care, psychology, and even mediation, as institutions relevant for the latter are usually located in cities. Thus, as Iversen $e t$ al. (2002) point out, rural doctors must cope with number of medical/non-medical/social challenges and carry more responsibility within the community - they are not explicitly primary care doctors, but "specialists-generalists", whose work is socially vital. Iversen revealed that doctors' actions and decisions are socially visible and commented by the surrounding social environment, exactly as their professional roles, duties and commitments. Rural societies' expectations are demanding, leaving no space for practitioners to take their minds off the community. Practitioners working in institutions as vibrant as rural clinics play the roles of social entrepreneurs, or in other words "boundary crossers" (Farmer and Kilpatrick 2009),

"who live in the rural community and are employed in the health system and so are able to use the lens of a community member to analyse and lead actions to build and use community capacity for health development. They can do so, because they operate in, and across, two or more social fields, including health" (Kilpatrick et al. 2009, 286).

However, I am not entirely sold by these enthusiastic declarations. How should we look at modern medical practice, taking into account the above mentioned research and a vast body of critical literature, revealing progressive and globally universal liberalisation of healthcare systems? Are the primary care doctors an exclusion or perhaps anthropologists should look more carefully for hidden agenda in primary care? 


\section{REFORM AND ENTREPRENEURSHIP(S) IN POZ}

Since 1997 the Polish healthcare system has been undergoing intensive reconstruction. As Peggy Watson (2013) critically remarks, the considered reforms, although necessary, have provoked massive inequalities among Polish patients exposed to fiscal regulations. These reconfigurations, however, have also confused doctors. The reforms, as doctors and researchers have revealed, have been inconsequent and in many aspects socially unjustified or simply misguided (Kowalska-Bobko 2017). After series of changes, the 1997 reconstruction plan, seen as a long-awaited liberal transition in healthcare, has lost its original aims. As a consequence, practitioners have had to continually invent new strategies for familiarising themselves with the incoming concepts of healthcare. But what exactly has changed in healthcare and how has it affected primary care?

The key person here is Jerzy Buzek, whose government in 1997 initiated reconstructions in healthcare system. Similarly to other countries in the Eastern Bloc Before, and for a while after 1989, in Poland almost all medical units were centralised and state-dependent. Although guaranteeing free access to procedures, the bureaucratic and ineffective system was eroded by corruption, cronyism, poor standards, and social inequalities, which together translated into a phenomenon I call "a culture of disappointment".

The goals of this undoubtedly difficult reform centred upon social insurance reconstruction, decentralisation, debt reduction, and the introduction of new healthcare providers - non-public, private agents headed by medical professionals, who were contracted by the newly-established paying institutions (Kowalska-Bobko 2017). Since 1997, the core of the healthcare budget has been made up of new social insurance contributions. In the period between 1997 and 2003, healthcare insurance, which is a component of social insurance, was managed by 16 regional Kasy Chorych ("Health-insurance Funds"), which were the paying institutions responsible for contracting medical services. In 2004, after a spate of criticism focused on unequal budgets and unclear bureaucracy, the Kasy Chorych were replaced by the Narodowy Fundusz Zdrowia (NFZ, "National Healthcare Fund") which is now the sole public institution financing medical services. Each January/February the NFZ signs contracts with healthcare providers. The NFZ's regulations set a price for each medical service and regulate the amount of money transferred to a healthcare provider. Additionally, the NFZ transfers a basic rate for each patient referred for surgery to contracted healthcare providers (for example to POZ). This rate is called the stawka kapitacyjna ("capitation rate"), and it might differ each year as well as for patients of varying ages and with distinct conditions.

Most significantly, however, the reform introduced new a primary care system based on Western models. The system - the Podstawowa Opieka Zdrowotna (POZ) - was opened up to the market, as the state was no longer able to cover the high costs of organising care at all levels. Practitioners were encouraged to establish partnerships, operating on the basis of contracts signed with the paying institution. 
Simultaneously, previously state-run surgeries were gradually transformed into partnerships. This process was completed in 2004. The contract's value varies between each surgery. The final sum results from the number of patients assigned to a surgery, multiplied by the value of a capitation rate linked to each "type" of patient. Additionally, contracts include separate capitation rates for the services of doctors, nurses, and midwives. Surgeries must cover all of their costs, including outsourced medical and laboratory examinations, fixed costs, taxes, and salaries, from budgets made up from the above-mentioned contributions. After settling all debts, the rest of the money is the doctors' income, divided up differently in each clinic. In some clinics, self-employed doctors with an independent medical practice issue a bill to the clinic for their services on a monthly basis. In others, the final income is divided between the doctors according to internal regulations outlined in a particular partnership's agreement. Consequently, many medical practitioners have become managers and employers, balancing costs and competing with other clinics. This competition is becoming heated, as the big-name medical companies are systematically taking control over the primary care market.

It seems, therefore, that the reconstruction of Polish primary care was - contrary to the Alma Ata declaration - ultimately focused on economic and legal aspects, with only a secondary focus on community matters. Thus, Poland fits well into a process, which Craig R. Janes describe as follows:

"Over the past twenty-five years the community-focused principles of comprehensive primary health care, set forth in Alma Ata declaration of 1978, have been replaced by efficiency lead reforms which advocate for a universally available but minimum package essential health care and public health services" (Janes et al. 2006, 6).

This appears to be confirmed in my research. Many times doctors rationalised the need for more economic freedom in healthcare, apparently undervaluing other goals of their practice. How, therefore is it possible to understand entrepreneurship in POZ? Based on the collected data, I suggest this entrepreneurship should be divided into two distinguished approaches. I consider them as a consequence of the series of succeeding healthcare reforms, and, although the proportion between them lacks the balance postulated in Alma Ata, they should be investigated together. The first approach, characteristic to a vast majority of informants, regardless of their educational background and location, manifests in the discourses and practices revealing doctors' attachments to liberal values. Here, two elements attracted my attention:

I. doctors as people of business, balancing costs, planning, and earning money;

2. the "cult" of private property, considered by doctors as liberation from the state's unfavourable gaze.

This is not surprising after taking into account the ethnographic testimonies denuding progressive liberalisation in global healthcare systems (Rylko-Bauer and Farmer 
2002; Mulligan 2015; Keshavjee 20I4; Janes 2004; Janes et al. 2006; Stone 1997). As Deborah A. Stone critically states,

"In the late twentieth century, the doctor has been reconceived as an entrepreneur who is no in the business of insuring patients as well as caring for them. [...] As medicine become professionalized, the role of money in the doctor-patient relationship became highly controversial" (Stone 1997, 534).

I partly agree with her criticism, although I consider it as generalising one. The US healthcare system in Stone's work, cannot be treated as a reference point for the Polish context. Thus, I recognise a second entrepreneurial approach in POZ, albeit rarer and less obvious than the business-oriented ideology. It is manifested in the form of mostly informal and spontaneous attitudes, actions, and intentions of doctors who, as well as business activity, appreciated pro-community aspects of their work and maintained a variety of non-professional relations with patients. However, these relations rarely were used by doctors to fulfil their roles as social entrepreneurs who stimulate communities or implement social innovations. The geographic context, contrary to Farmer and Kilpatrick's (2009), Kilpatrick's et al. (2009) and Iversen's et al. (2002) revelations, was also less distinctive. Indeed, doctors in Warsaw were mostly (except one informant) embedded in strictly neoliberal discourses and practices, leaving community matters almost completely aside. This does not mean, however, that similar attitudes were unheard of in other locations, including rural areas. Doctors there were also attached to liberal values, as their clinics operated under the same conditions as those in urban settings. And yet, in rural areas I met and observed practitioners who more often devoted themselves to patients and community matters. However, their actions were limited to spontaneous and unstructured activities or to non-medical relations based on reciprocity. Despite that, I consider these interactions as unique. Based on the collected data, I suggest that they should be investigated as local manifestations of social entrepreneurship - admittedly not fitting any of the mentioned definitions - but nonetheless contributing to the variety and depth of doctor-patient relations.

\section{PEOPLE OF BUSINESS}

The business roles of doctors has been often investigated as a global threat (Janes 2004; Janes et al. 2006; Stone 1997; McKenna 2012, 20I0). Healthcare systems and doctors, researchers argue, gradually turn from patients' suffer and channel their attention on standardisation and market-grounded care (Abadía-Barrero 20I5; Mulligan 20I5, Czachowski 2002, 2005). The data under consideration here seems to support this thesis, however, I consider the process of liberalisation in Polish healthcare as still less radical. This is clear in doctors' declarations, where calls for more profound reforms could be outlined. Here is an example: 
"The reform is to upgrade something, to upgrade financing. According the last reform, money is supposed to follow patients. Perhaps this is the case somewhere in secondary care surgeries, but not here" (man, 63, owner, Podlasie).

Most practitioners, with no difference between urban and rural, expressed their perspectives on healthcare in a neoliberal language. With few exceptions, they talked about a "healthcare market" rather than a welfare system, favoured limitations on insurance or postulated co-payments for consultations. "If she had to pay five zloty, then she wouldn't be here so often" - said a rural clinic owner, when asked about patients who often visit doctors. Practitioners often complained about insufficient progress by successive governments, who have been unable to implement "real" (doctors' terms) reconstructions, with the aforementioned co-payment as a flagship idea. The doctors' position was clear - the costs of medical services are higher than the health insurance rate, thus some constraints or additional payments are simply inevitable.

Generally, practitioners perceived the 1997 reform as "normalising", where normalisation - a process implementing a liberal economy - should be read as a crackdown on the remnants of "unfair socialism". A new form of medical practice - based on private ownership, economic activity and contracted services - as the doctors told me, was warmly welcomed, since it was the only reasonable idea for organising primary care and ensuring a high standard of services. Shortly after 1997, running one's own business became the right way to be a "modern" doctor, whose social and economic capital corresponded with heavily idealised images of "Western" doctors earning a lot of money and occupying a key position in healthcare systems. Thus, the successive reforms clearly altered doctors' identities, which are now based on attachment to private ownership and business entrepreneurship. As one of the doctors said:

"Now, doctors know that they have a budget, they know what they manage, they know what they can do. In the past everything was unclear, the money was different, the salaries low. Now, doctors, like in every country, earn according to their scope of duties and responsibilities" (woman, 54, coowner, Białystok).

Founding a POZ clinic, or even working in one, empowered doctors authority and enriched them with a new vision of medicine. The doctors gained access to additional training. Some respondents participated in coaching sessions and many completed postgraduate management studies. Doctors can implement some innovative medical, organisation and management solutions in their practices. Nevertheless, all these amenities cost money and doctors must balance their budgets. Consequently, the reform, apart from "normalisation," also brought a "price revelation". Doctors discovered medicine costs - prior to 1997 , the centrally distributed money was an abstract 
issue managed by people in administrative institutions. Now, practitioners are forced to control spending, as their clinics are companies prone to financial turmoil:

"If I were supposed to do this lege artis, then I would spend all of my money. Let's say I have somebody with hypertension and I going to examine him with the whole battery of examinations - then, with such approach to every single patient, I would run out of money. It is simply impossible" (woman, 64, owner, Podlasie).

This discovery has had profound consequences for doctors, who must now be fluent in accounting and socio-economic factors affecting their profits. Nevertheless, business entrepreneurship has opened up many new possibilities to doctors and offered them a certain independence from the state. They consider themselves as practitioners and businesspeople having more responsibilities than just treating people. As one of my informants said,

"It is just as in every other business, but, as the owner and the employer, I have certain duties. I must keep an eye on my nurses, on their social insurance, I have to follow labour laws, and besides, like every employer, I must take care of health and safety issues. In the big surgeries there was a director and his or her deputy, taking care of everything. And here, I am a director and deputy, I am the owner, stockist, hauler, literally everybody!" (man, 5o, owner, Podlasie).

Summing up, becoming a doctor-businessperson in a non-public surgery was a "cultural revolution" - a new way of practising medicine in Poland. As Stone (1997) pointed out, the practitioners who are often entrepreneurs preoccupied with monthly income and the costs of running their businesses, introduced market economics to their daily practice. Such intrusions entail new concepts of understanding medical practice. As my observations revealed, doctors (even contracted) rarely treated patients lacking social insurance. They explained this with alleged difficulties in recovering their costs from NFZ or were concerned about potential consequences (mostly financial) of serving patients without the right to state-refunded healthcare. Furthermore, they referred patients for examinations only in "justified situations" (doctors' term), even under the threat of accusations of parsimony. The doctors are not afraid of asking "market questions" and defending their economic position, which was demonstrated during strikes in 2003-2005 when they successfully blocked the state's attempts for further reconstructions in POZ. The emergence of the Porozumienie Zielonogórskie ("Zielona Góra Agreement"), an association of healthcare employers representing the collective interests of POZ doctors, has significantly reshaped the health-policy scene. By criticising government activities, practitioners articulated their objection to "distorting" (doctors' term) the essence of the 1997 reform, namely unhampered entrepreneurship and market pricing for services. 


\section{SOCIAL OR RECIPROCAL ENTREPRENEURS?}

"Not only market mechanisms, statistic or however we name it, decide the quality and significance of this job" - said one of the informants. So, what else does? First, the quality, intensity and durability of professional relations that doctors maintain with patients. Secondly, the variety of non-professional interactions between doctors and patients. And finally, the doctors' potential - unique to Polish healthcare - for switching between medical and non-medical interactions, resembling Farmer's and Kilpatrick's (2009) "boundary crossing".

The Polish healthcare system is commonly described as a treadmill, where powerful institutions dwarf vulnerable patients (Watson 20I3; Piątkowski 20I5). Many of my informants left hospital jobs, frustrated with the intense nature of the work and poor contact with the ill. Moving to POZ was, then, a chance for better relations with patients. Despite doctors' complaints about the institutionally imposed rush, in POZ they have more time for patients; if necessary, they may prolong consultations and this practice was common among practitioners - more often in rural areas - whose patients required non-medical support:

"The rural doctor was like a priest - you could have a word with him. The older people still do this.

I have a patient abused by her daughter-in-law. Nobody knows, but I know. She comes to me and doesn't want to leave, cries, wants to talk. Do you think this consultation lasts ten minutes? No. It lasts for half an hour" (man, 63, owner, Podlasie).

Thus, time determines the intensity and depth of relations in POZ. The collected evidence suggests that there are two distinctive forms of experiencing time by doctors. I consider them as structures of experience (Mattingly 1998), as they introduced an order in the narratives and revealed how practitioners conceptualised their work. The time established frames for relations with patients and channelled doctor's attention on their needs. Time is the agent powering doctors' actions and turning them into meaningful socio-cultural practice - into care.

The first time frame was commonly mentioned as "ten minutes". This institutionally standardised period, according to NFZ, is a sufficient period for a consultation in POZ. "Ten minutes" establishes the rhythm of doctors' work and specifies a number of daily admissions. Doctors used this measure to depict intensive interactions with patients, mostly deprived of meaningful contact with their stories, bodies, and expectations. For many, such consultations, overloaded with bureaucracy, were a symbol of failure of the idea of primary care, where personal interactions are essential. Is also appears that "ten minutes" is the optimum period of interaction commonly reached by quantitative researchers, whose conclusions easily percolate into Polish public and scientific discourses. Here is an example: 


\begin{abstract}
"The research has revealed that most of the admissions in POZ are official. Establishing polite relations, explaining the disease's background, and dialogue about the right treatment are rare. Moreover, negative interactions, like lack of eye contact, limited information, complex language, criticism, lack of empathy, showing off, or shortening the consultations by doctors increase the level of patients' disappointment" (Holecki et al. 2013, I5I).
\end{abstract}

The second time frame, rarer and thus more elusive, is a long perspective through which doctors looked at patients' biographies, conditions, body-mental changes, and family and personal environment. This form, much harder to grasp in quantitative inquiry, cements the quality and durability of relations. It lays a foundation for doctors' non-medical involvement and interaction with patients. This was observed predominately in rural and small town settings, however, informants working in Białystok also spoke about how such deep structures bring significant knowledge about patients:

\footnotetext{
"We are the doctors sensu stricto, because, after so many years, we know people. I see them in a different way. The patient comes in and I ask - why are you so thin? She said, she was nervous because of surgery. No - I said. How much have you lost on weight? Miss, you don't lose weight just like that, what about your thyroid? Then, quickly she had surgery and later some fits due to thyroid hyperactivity. A [hospital] doctor didn't know her. But I know many generations, it is enough to me to just have a single look" (woman, 64, owner, Podlasie).
}

This knowledge, as informants argued, is the essence of primary care. To successfully perform their duties, doctors must transform it into practice of "knowing", which was possible only after a long period of "ten minute" interactions, ineffective in and of themselves, but informative when accumulated. Thus, a key to deeper mutual relations was in doctors' mental processes of relocating patients from the short time frame and placing them in the longer axis. Although, in the majority of narratives the long-lasting relations were presented as crucial to efficient medicine, simultaneously they designated a space for deeper interactions between practitioners and patients. In this space the informants offered their knowledge, views, and experience - as the social entrepreneurs or "bounder crossers" do - to their patients in need. This commitment was more visible in rural areas, where patients usually received more help than defined by the contracts. Although they complained about "the system, which doesn't see their commitments", the practitioners voluntary offered their patients secondary care, which is often hard to access for rural communities:

"I do this for my patients. I do this for Mr X, as he can't go there, he has no money, he will never be admitted to a surgeon. [...] I am a small-scale surgeon, a small-scale gynaecologist, a small-scale oculist, a small-scale dermatologist" (man, owner, 6I, Mazowsze).

Such doctors established deeper connotations - often founded on the principle of exchange - with their patients. Although it would seem fundamental to cultural 
activity, these forms of interactions are rare in the field of healthcare. Known examples of bribing and controversial gifts cannot be treated as reciprocity, which - in contrast to bribery - favours long mutual relations and meaningful communication between involved parties. The reciprocity is not a literal form of social entrepreneurship, however I see it as business-independent example of doctor's social involvement. In contrast to Farmer's and Kilpatrick's (2009) interpretation, I do not place the reciprocity interactions among the examples of boundary-crossing practices. I would rather propose to consider these relations as primary to any further commitments, as a pact initiating mutual cooperation and establishing new and intense relations of trust and attachment. Thus, I would call practitioners who establish reciprocal interactions with their patients "reciprocal entrepreneurs". This identification corresponds more accurately with the data under consideration here and below I provide some examples.

\section{Case study 1}

Mrs. M. owns a clinic in Białystok, which she has been running for fifteen years. She is well known to her patients who sometimes - in gratitude - bring her sweets and food. Usually, she shares the gifts with her nurses or gives them to poorer patients. Sometimes, however, she uses them to initiate a reciprocity. M. brought me the story of her unusual relationship with D. - a patient working in the court archives. M's husband is a keen gardener, growing vegetables which require special twine to support them. As D. has access to "a high-quality string to binding files and perfect for gardening", M. has established an exchange with D. - sweets/food for string. Such string can be bought for pennies, contrary to delicious home-made food brought by patients. But the price is not the point here. M. and D. entered the interaction where goods are exchanged - as in Malinowski's kula [ring] - symbolically and coalescent relations of mutual trust, respect, favours, and commitment. The circulation of goods brought them closer and enabled a complex exchange of knowledge, gossips, gestures and favours. They exchange books and recipes. They share knowledge about the neighbourhood and useful contacts for their professional and personal lives. Clearly, M. crossed a boundary, and came down from a level of professionalism, but - as I have learned observing her other reciprocal interactions - she reached the daily life and matters of her patients.

\section{Case study 2}

Mr. S. is a doctor living in Warsaw but working in the rural part of Mazowsze. He painted a vivid picture of a contemporary rural community, where primary care doctors are still respected and help those in need. However, these needs can be surprising. One evening he received a call from a poor couple, who were patients, asking for medical assistance. Although he was not obliged by the contract, he drove out to the patients' home only to discover that this time the patients were unusual. Two pigs - a sole precious possession of these people - were ill. After his initial shock, S. gave them some 
analgesic medicine and drove back home. The next day the pigs felt better and their owners came grateful with some gifts of food. S.'s conclusions about this story were truly "ethnographic". He realised how much he was respected, but also how much social responsibility he had. Additionally, he recognised the social context of this event - after receiving small gifts of food, which he couldn't refuse for fear of causing insult, he entered a relation of trust, favours, reciprocity, and care with his patients, who passed on the news about the selfless doctor to other community members, enforcing his position and giving him - a newcomer from Warsaw - a chance to establish much deeper relations with them, people of a rural area sharing local worldviews.

\section{CONCLUSIONS}

Contemporary Polish primary care sits between two "clashing civilisations": a neoliberal and standardised biomedicine competing with healthcare understood as a public system of social welfare (McKenna 20I2). I consider the commodification of global healthcare and transitional context of medicine in a post-socialist state as the key factors responsible for this major split. Today, POZ doctors must run their clinics-companies as businessmen do, and simultaneously remember about the pro-community goals of their practice. Thus, they are squeezed between distinctive forms of entrepreneurial activity. As my research has revealed, balancing the two was not easy. Therefore, I am not persuaded by research revealing an idealised picture of doctors voluntary devoting themselves to their community. Perhaps true for the other countries' field context, however, such conclusions sharply contrast with the picture I found among Polish primary care professionals, apparently confused with the conflicting discourses, laws, and expectations shaping their work - or perhaps mission. They did not have any coherent idea about how to combine a pro-community "Health for All" strategy (partially reflected in the goals of the 1997 reform and in public expectations) with an attachment to market-based values. As one of the informants said, "the clinics are social companies", however, she failed to explain, how much they were "social" - and how much they were "companies".

I do not blame the doctors for their business orientation. I believe the reasons for a certain failure of a pro-community approach in POZ lie elsewhere. Polish healthcare is far from stable. Shifting politics and economies are reflected in cyclically changing health policies, exposing patients and professionals to incoherent institutional discourses and requirements. In such chaotic settings the doctors were unable to establish their professional identities and identify the core values of their work. My observations suggest that this conflicting situation is additionally exacerbated by POZ doctors' unclear social perception. "Traditional" concepts of a free, state-provided "family medicine", and "modern", neoliberal settings of medical practice clash here, however, 
the former seems to currently be prevailing, and yet is not meeting the economic and legal frames of contemporary healthcare in Poland. These remarks find support in the doctors' critical conclusions about patients lacking knowledge about the rules regulating the healthcare system. However, as they pointed out, there are no places where patients can educate themselves, nor there are institutions encouraging them to do so.

Although doctors focus on business entrepreneurship, I still consider primary care practitioners as unique in Polish healthcare. I found many of them eager to establish deeper relations with patients, and some of them maintained unobvious and surprisingly "ethnographic" interactions of reciprocal commitment with them. The latter were usually enriched by doctors' reflexive approaches to primary care and community matters - as M.'s and S.'s examples have demonstrated. Doctors operated with complex time frames and performed elaborate mental processes of transferring interactions with their patients from meaningless consultations, reduced by institutional limitations, to spaces filled with "knowledge" about patients and their dilemmas. This knowledge was crucial to reaching further than merely seeing to temporary body conditions. It was a cornerstone of multigenerational and long-lasting insights into patients' life trajectories, body-mental transformations, and changes in their social environment. Here, the informants recognised a space for fulfilling the social mission of primary care. Nevertheless, according to my respondents, the recent standardisation and bureaucratisation in healthcare has significantly reduced opportunities for such commitments. This adverse shift manifests itself as a transition from a subjective approach, where patients' stories and descriptions of symptoms, along with the physician's interpretations were fundamental, to time-compressed and standardized procedures reflecting bureaucratic patterns of treatment. This, as respondents suggested, undermines community and patient-oriented care. In the bureaucratic healthcare of today, they argued, the opportunity for deeper doctor-patient relationships has been limited. The long time frames are now difficult to maintain, as NFZ's overwhelming standardisation questions their value, or simply ignores them. Despite this, the practitioners still made efforts to enjoy "knowing" rather than "serving" the patients, although it is hard to estimate, how long they can persevere in this institutionally unwelcome bridgehead of voluntary flair.

\section{BIBLIOGRAPHY}

A b a día-B a r rero C.E. 20I5. Neoliberal justice and the transformation of the moral: the privatization of the right to health care in Colombia. Medical Anthropology Quarterly 30 (I), 62-79.

Aust in J., Steven so n H., We i-Skille r n J. 2006. Social and commercial entrepreneurship: same, different, or both? Entrepreneurship Theory and Practice 30 (I), I-22.

$\mathrm{Cu}$ e to M. 2004. The origins of primary health care and selective primary health care. American Journal of Public Health 94 (II), I864-I874. 
Cer to T. and Mille r T. 2008. Social entrepreneurship: key issues and concepts. Business Horizons 5I, 267-27I.

Czachowski S. 2002 Środowiskowe uwarunkowania praktyki lekarza rodzinnego (wybrane zagadnienia). Toruń.

Cza chowski S. 2005 Rola lekarza rodzinnego w praktyce medycznej. Toruń

Farmer J. and Kilpatrick S. 2009. Are rural health professionals also social entrepreneurs? Social Science \& Medicine 69 (II), I65I-I658.

Holecki T., Skrzy pek M., S zl a p a M. 2013. Kształtowanie wizerunku placówki podstawowej opieki zdrowotnej w kontekście roli lekarza rodzinnego. Studia Ekonomicznel Uniwersytet Ekonomiczny $w$ Katowicach 157, I49-156.

Iv e r s e n L. 2002. Workload pressures in rural general practice: a qualitative investigation. Scandinavian Journal of Primary Care 20, I39-I44.

J a n e s C. R. 2004. Going global in century XXI: medical anthropology and the new primary health care. Human Organisation 63 (4), 457-47I.

Janes C.R., Chuluundorj O., Hilliard C.E., Rak K., Janchiv K. 2006. Poor medicine for poor people? Assessing the impact of neoliberal reform on health care equity in a post-socialist context. Global Public Health $\mathrm{I}(\mathrm{I}), 5-30$.

Ke n n ed y M. D. 2002. Cultural formations of post-communism emancipation, transition, nation, and war. Minneapolis.

Keshavjee S. 20I4. Blind spot: how neoliberalism infiltrated global health. Oakland.

Kilpatrick S., Cheers B., Gilles M., Taylor J. 2009. Boundary crossers, communities, and health: exploring the role of rural health professionals. Health \& Place I5 (I), 284-290.

Kow alsk a-B o b k o I. Decentralizacja a systemy zdrowotne. W poszukiwaniu rozwiąań sprzyjajacych zdrowiu. Kraków.

Mattingly Ch. 1998. Healing dramas and clinical plots. The narrative structure of experience. Cambridge.

Mc Ke n n a B. 20I0. Take back medical education - the "primary care" shuffle. Medical Anthropology 29 (I), 6-I4.

Mc Ke n n a B. 20I2. The clash of dedical civilizations: experiencing "primary care" in neoliberal culture. Journal of Medical Humanities 33 (4), 255-272.

$\mathrm{Mull}$ ig a n J. 20I5. Insurance accounts: the cultural logics of health care financing. Medical Anthropology Quarterly 30 (I), 37-6I.

Piątkowski W. 20I5. Dysfunkcjonalność systemu opieki zdrowotnej w polskiej socjologii medycyny. Zarys problematyki. In A. Ostrowska and M. Skrzypek (eds.), Socjologia medycyny w Polsce z perspektywy pótwiecza. Nurty badawcze, najważniejsze osiagnięcia, perspektywy rozwoju. Warszawa, 67-IO4.

P iąt kowski W. and Nowak ow ska L. 20I2. System medyczny w Polsce wobec wyzwań XXI w. Perspektywa krytycznej socjologii zdrowia i choroby. Przeglad Socjologiczny 62(2), II-29.

R ho des L. A. 1996. Studying biomedicine as a cultural system. In C. F. Sargent and T. M. Johnson (eds.), Medical anthropology: a handbook of theory and method. Revised edition. London, 165-180.

Rylko-B a u e r B. and Farmer P. 2002. Managed care or managed inequality? A call for critiques of market-based medicine. Medical Anthropology Quarterly i6 (4), 476-502.

S t o n e D.A. 1997. The doctor as businessman: the changing politics of a cultural icon. Journal of Health Politics, Policy and Law. 22 (2), 533-556.

Th o m p s on J. L. 2002. The world of social entrepreneur. The International Journal of Public Sector Management I5 (5), 4I2-43I. 
Wat s o n P. 20I3. Catastrophic citizenship and discourses of disguise: aspects of health care change in Poland. In P. Watson (ed.), Health care reform and globalisation. The US, China and Europe in comparative perspective. Abingdon, II8-I39.

W ł o d a r czyk C. 200o. Podstawowa opieka zdrowotna jako kategoria polityki zdrowotnej. In A. Czupryna, S. Poździoch, A. Ryś, C. W. Włodarczyk (eds.), Zdrowie publiczne. Wybrane zagadnienia, t. I, Kraków, 213-228.

\section{Author's address}

Hubert Wierciński PhD

Institute of Ethnology and Cultural Anthropology

The University of Warsaw

ul. Żurawia 4, O0-503 Warsaw, POLAND

e-mail: hubertwier@gmail.com

ORCID: 0000-0002-9535-4180 